\title{
Ornamental plants in Chapecó: market characteristics and opportunities for family farms
}

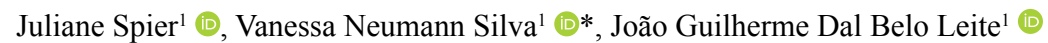

${ }^{1}$ Universidade Federal da Fronteira Sul, campus Chapecó, Chapecó-SC, Brazil.

\begin{abstract}
Floriculture is very lucrative to small producers as it requires small land areas, with usually short production cycles. The region of Santa Catarina West in Brazil has growth potential in the cultivation of ornamental plants, although it is not practically observed, as the productive chain of this sector has little or no organization, making it imperative to study the causes of this problem. Therefore, the aim of this study was to characterize the productive chain, market, and commercialization of ornamental plants in Chapecó-SC. The proposed study was carried out in an integrated manner in Chapecó-SC, through structured interviews with farmers, traders, and consumers of flowers and ornamental plants. The study sample consisted of 45 consumers, 24 producers, and 18 commercial establishments. Only three producers of ornamental plants in Chapecó were identified among the participants interviewed, although $84 \%$ believed that the municipality has demand for floriculture products, and only $21 \%$ of the interviewees have thought about cultivating ornamental plants. The market and commercialization of flowers and ornamental plants in Chapecó are dependent highly on the supply of products from the state of São Paulo, especially form the region of Holambra. The commercialization is predominantly in supermarket chains, for ease of access to consumers. The primary factor affecting the commercialization of ornamental plants is the price, because a dearth of producers in the region leads to an increase in the price, especially due to the long transportation.
\end{abstract}

Keywords: alternative income, floriculture, small farms.

\section{Resumo}

Plantas ornamentais em Chapecó-SC: características de mercado e oportunidades para agricultura familiar

O setor da floricultura é muito atrativo para agricultores familiares, uma vez que demanda pouca área de terra e o ciclo de produção, de grande parte das espécies para esse fim, geralmente é curto. A região do Oeste Catarinense tem grande potencial de crescimento no cultivo de plantas ornamentais, porém, não é o que se observa na prática, havendo pouca ou nenhuma organização da cadeia produtiva desse setor. Desta forma, faz-se necessário estudar as causas dessa problemática. Sendo assim, o objetivo desta pesquisa foi verificar qual é a dinâmica envolvida na produção, comercialização e consumo de plantas ornamentais em Chapecó-SC. O estudo foi realizado no município de Chapecó-SC, por meio de aplicação de entrevistas estruturadas, com produtores rurais, comerciantes e consumidores de flores e plantas ornamentais. O tamanho da amostra da população foi: 45 consumidores, 24 produtores e 18 estabelecimentos comerciais. Foram identificados apenas três produtores de plantas ornamentais em Chapecó. Apenas $21 \%$ dos entrevistados pensaram em produzir plantas ornamentais, embora $84 \%$ acreditem que o município tenha demanda para os produtos da floricultura. O mercado e a comercialização de plantas ornamentais em Chapecó são altamente dependentes da oferta de produtos vindos do estado de São Paulo, especialmente da região de Holambra. A comercialização predominante é realizada em redes de supermercados, pela facilidade de acesso aos consumidores. $O$ fator preço é o quesito principal na comercialização das plantas ornamentais, e a falta de produtores na região faz com que se elevem os preços, especialmente em função do longo transporte necessário.

Palavras-chave: alternativa de renda, floricultura, propriedade agrícola familiar.

*Corresponding author: vanessa.neumann@uffs.edu.br 


\section{Introduction}

Production and sales of ornamental plants in Brazil are commercially promising sectors. Despite the recent economic slowdown, with negative Gross Domestic Production growth (GDP) for the most part of 2014 to 2017, the returns from commercial floriculture have been on the rise. Facilitated by modern and intensive production systems, and concentrated in the South and Southeast regions of Brazil, floriculture grew 23\% from 2014 to 2017, at an average rate of $5.7 \%$ per year, with an estimated total market of R \$ 7 billion (Junqueira and Peetz, 2018).

Production of ornamental plants is well-adapted to small areas, such as farms of 6.5 ha on average, and is an income opportunity for family farms, with revenues ranging from $\mathrm{R} \$ 50,000$ to $\mathrm{R} \$ 100,000$ per ha per year (Duval, 2014). Floriculture is an intensive agriculture practice with the per unit area income much higher than any other branch of agriculture (Manikas et al., 2019).

According to Nascimento et al. (2019), in the most recent years, floriculture, among other activities, has become an important vocation and income alternative in the rural areas, for families in the Southern Region of Brazil, and has been generically called new rurality. However, in Santa Catarina, where family-owned small farms are abundant, ornamental plant production remains limited. In 2014, state ornamental plant production accounted for only $7 \%$ of the area and $4 \%$ of national sales, according to Neves and Pinto (2015), who state that the underlining causes for such poor participation remain rather blur. The lack of skilled labor, low technology, and production intensification, deficient logistics, and market limitations are undermining the commercial take-off of ornamentals in Santa Catarina. Alternatives to boost ornamental plant production are particularly important in the West region of the state, where smallholder farmers who fail to meet economies of scale and industrialization standards struggle with returns from traditional agroindustrial activities, such as animal production. Thus, to maintain the same level of income, farmers tend to expand the scale of activities and increase the volume of production, consequently increasingly concentrating the production to a limited number of establishments. In this way, the "squeeze on agriculture" promotes specialization in swine production and accelerated scale-up, without a guarantee of an economic return consistent with farmers' social needs. The result of this is a socioeconomic and environmental crisis occurring in the region as the family farmers are no longer able to follow this "race" for advanced technological change and scale-up and end up getting excluded from the production process (Mello, 2013).

This article aims to explore the available information on the current market scenario (i.e., commercialization and consumption), production characteristics of ornamental plants in Chapecó, and opportunities for family farms in the region.

\section{Material and methods}

Farmers, sellers, and consumers of ornamental plants were interviewed from August to October of 2018, through a semi-structured questionnaire (Table 1) in Chapecó, State of Santa Catarina. 
Table 1. Questions performed during the interviews.

\begin{tabular}{|c|c|}
\hline Group & Questions \\
\hline Plant producers & $\begin{array}{l}\text { 1- How big is your land area for cultivation? } \\
\text { 2- What are the sources of income on the property currently? } \\
\text { 3- How many family members survive and assist in rural work? } \\
\text { 4- Have you considered producing ornamental plants? } \\
\text { 5- In your opinion what are the biggest obstacles for those who produce ornamental plants? } \\
\text { 6- Do you believe that ornamental plant producers are well paid? } \\
\text { 7- In your opinion, Chapecó has a great demand for producers of ornamental plants? } \\
\text { 8- How many producers of ornamental plants, located in Chapecó and region, do you know? }\end{array}$ \\
\hline $\begin{array}{l}\text { Ornamental } \\
\text { plant outlets }\end{array}$ & $\begin{array}{l}\text { 1- What are the main demands of consumers in Chapecó? } \\
\text { 2- Do you consider the consumption pattern of the population of the municipality, as high, low, or } \\
\text { ideal? } \\
\text { 3- Are you concerned about choosing your plant supplier? What requirements do they have to } \\
\text { reach? } \\
\text { 4- Do you care about the origin of the products that you will offer in your establishment? } \\
\text { 5- Do you believe that if there were more producers in the region, factors such as the price of } \\
\text { products would decrease? } \\
\text { 6- What are the care and differentials to achieve high levels of customer satisfaction? }\end{array}$ \\
\hline $\begin{array}{l}\text { Ornamental plants } \\
\text { consumers }\end{array}$ & $\begin{array}{l}\text { 1- In general which species do you prefer most to consume? } \\
\text { 2- Do you have a habit of consuming plants at certain dates or occasions? What are these dates and } \\
\text { occasions? } \\
\text { 3- What is the average amount }(\mathrm{R} \$ \text { ) spent per year on ornamental plants? } \\
\text { 4- What do you usually observe when buying an ornamental plant? } \\
\text { 5- Would you like to be able to buy more plants? What is the biggest obstacle to higher } \\
\text { consumption? } \\
\text { 6- Do you usually worry about the origin of the plants you are buying? } \\
\text { 7- Do you believe that if there were more producers in the region the price of plants would be } \\
\text { lower? } \\
\text { 8- What do you take into consideration when choosing where to buy the plants? }\end{array}$ \\
\hline
\end{tabular}

Before the collection of any data, we submitted our methodological approach (including questionnaire) to the university ethical committee (approved in July 2018, registration CAAE 89179118.9.0000.5564). The sample size was defined based on the sampling formula proposed in Equation 1.

$$
n=\frac{N \times Z^{2} \times p \times(1-p)}{Z^{2} \times p \times(1-p)+e^{2} \times(N-1)}
$$

Where: $\mathrm{n}=$ sample size; $\mathrm{N}=$ population size; $\mathrm{Z}=$ normalized variable defined based on the confidence level; $\mathrm{p}=$ event probability; $\mathrm{e}=$ sampling error.

Our sampling strategy (i.e., Equation 1) is widely used as a guiding tool in a wide range of disciplines, which require the observation of a limited number of individuals to understand the targeted population (Spalla and Castilho, 2016; Pereira et al., 2019). In this study, we defined the confidence level at $95 \%$ (Z-value), event probability at $50 \%$ ( $p$-value), and sampling error at $15 \%$ (e-value). The population size (N-value) varied according to the target population. We assumed the total population of Chapecó, i.e., 220,367 inhabitants (IBGE, 2018), as ornamental plant consumers, and carried out 45 interviews. The population of the ornamental plant retail sector accounts for 21 establishments (Chapecó, 2018), for which 18 interviews were conducted.

Farmers or ornamental plant producers, on the other hand, require a different sampling approach. This is because information about their population size is absent in public records, such as in the municipality agricultural office. Experts, such as those at the municipality agriculture office, and other stakeholders commonly believe that the local population of ornamental plant producers is very low and that most of them bring their produce to a local farmers' market in downtown Chapecó. Here, we found three ornamental plant producers and interviewed all of them. Other 21 non-ornamental plant producers at the market were also interviewed to further characterize the family farms in Chapecó, particularly at farmers' markets. Ornamental plant retail establishments and consumers were randomly selected. Interviews were carried out in different neighborhoods and sales outlets, such as supermarkets and floriculture units.

The questionnaires were designed to characterize the ornamental plant market in Chapecó and highlight the 
main opportunities and challenges in the region. Relevant information from the questionnaire included (i) farmers: farm size, income sources, family labor availability, ornamental plant production, and market and production limitations; (ii) consumers: ornamental plant preferences (species), consumption seasonality, average expenditures, market limitations, and concerns; (iii) sales outlets: suppliers, consumers' demands and preferences, and challenges and opportunities.

\section{Results and Discussion}

\section{Ornamental plant producers}

A total of 24 farmers were interviewed ( 3 ornamental producers and 21 non-ornamental producers) at the farmers' market in downtown Chapecó, which is the busiest and largest market for family farmers in the municipality. Overall, they were small-scale producers, with $62 \%$ having up to 10 ha, $21 \%$ having between 10 and 20 ha, and only $17 \%$ with more than 20 ha of land. This is similar to Santa Catarina's census information of 2017, according to which $65 \%$ of agricultural establishments own up to 20 ha (IBGE, 2017).

The interviews with farmers also highlighted relatively high family labor availability, with $46 \%$ having $2-5$ family members engaged in farming activities, and 33\% having more than five family members engaged in farming. The most typical farm activities include vegetables and fruits, which are often associated with grains, ornamental plants, beekeeping, and others (Figure 1).

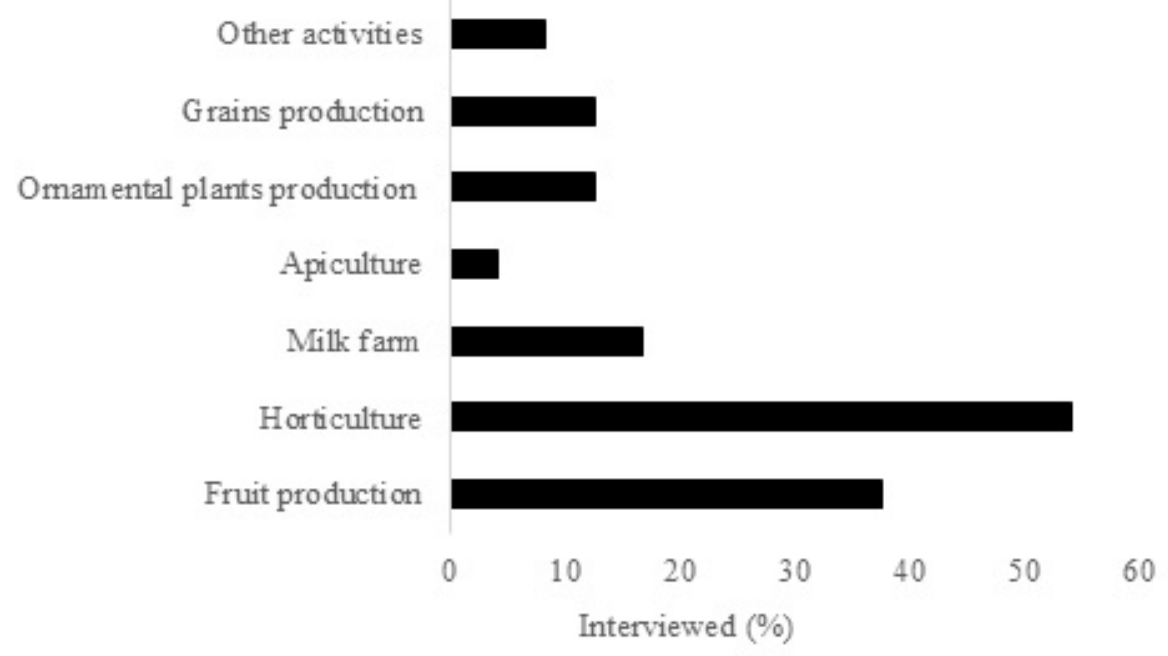

Figure 1. Frequency of farm activities among farmers at Chapecó's farm market $(n=24)$. Source: the authors

Only $10 \%$ of non-ornamental plant producers who participated in the interview $(n=21)$ have considered shifting their current agricultural activities toward ornamental production. The hurdles include lack of technical information (i.e., rural extension services), production costs, and market access restrictions due to small-scale production and quality and packaging standards. In addition, farmers engaged in traditional activities such as poultry, pig, dairy, soybean, and maize (CEPA, 2018) had made investments highly specific to their current farming requirements, such as buildings and machinery design for animal husbandry, and grains production. Likewise, poor access to information combined with limited entrepreneurial opportunities to lure farmers toward floriculture has been underlined as major setbacks to expanding the sector in South Brazil (Terra and Züge, 2013).

On the other hand, ornamental plant producers also find many challenges to prosper, and income is one of the primary limitations. Our interviews with ornamental plant farmers $(\mathrm{n}=3)$ in Chapecó highlight an overall disappointment with revenues. Two farmers revealed that their incomes from ornamental plant sales were insufficient (i.e., high opportunity cost), and one farmer found ornamentals sufficient, with ups and downs during the year. A second limitation, which likely affects farmers' income, was found to be technical assistance. All farmers, who took the interview, found that technical assistance toward ornamental plant production to be insufficient or completely absent. Without technical knowledge, farmers are unable to implement best agronomical practices, adjust management, and perfect their decision making, thus, leading to production inefficiency and economic losses.

Being small-scale, ornamental producers in Chapecó are unable to comply with quality, volume, and frequency standards to access relatively large retail outlets, such as supermarkets and flower shops. Access to markets, therefore, is the third most important limitation. Farmers struggle to compete with the wide diversity of retail and relatively low prices. Moreover, while consumers can find ornamental plants at the retail seven days a week, from 
morning to evening, the 'farmers market' is only open two days a week, only in the mornings. Inequality in market access caused by the exclusion of small-scale farmers from agri-food supply chains has also been reported in different regions of the world (Reardon et al., 2012). The main causes include changes in consumer preferences, food safety concerns, and the rise of international retail chains, such as supermarkets, which reshaped the dynamics underpinning modern supply chains (Van der Meer, 2006). The growth and increasing concentration of supermarkets favor more vertically coordinated market systems, allowing retailers to standardize quality, ensure consistent supply, and achieve economies of scale of perishable goods (Boehlje, 1999). According to Hummel and Miguel (2017), the biggest efficiency of retail chains in terms of quality and availability of floriculture products in several regions of Brazil achieved a strong evolution of sales to final consumers. However, floriculture specialized stores fell steadily throughout that period, due to strong competition from food retailers. In this process, traditional, often smallscale, spot markets lose space to specialized wholesalers (Berdegué et al., 2007).

Collective action is one way for smallholder farmers to access modern value chains. Cooperatives can be an efficient way for small farmers to meet quality; according to Higuchi (2014), membership in an agricultural cooperative can improve production efficiency, for instance, by providing services such as storage and transport (ArcasLario et al., 2014).

In Brazil, cooperatives prove to be essential for farmers to gain economies of scale and access market opportunities, particularly in the ornamental plant sector. Commercial floriculture practiced in Brazil is concentrated (48.9\%) in São Paulo State, particularly in the regions around the municipalities of Atibaia (Atibaia, Mogi das Cruzes, Suzano, and others) and Holambra (Holambra, Santo Antonio de Posse, Campinas, and others). From these regions, supply flows of short, medium, and long distances are organized, that manage to bring the flowers and ornamental plants of São Paulo at least to the capitals and main poles of consumption in the whole Brazil (Junqueira and Peetz, 2018).

Recently, Veiling Holambra Cooperative, for instance, started doing business as an independent organization, although its history goes back to 1948 when the parent cooperative was established as part of an emigration project between the Netherlands and Brazil (Teixeira et al., 2017). Then, the producers knew little about flowers, and the cooperative provided training and hired technicians to assist them. This support was decisive for the development of the sector, encouraging the construction of greenhouses and the cultivation of potted plants. In the 1980s, several Dutch producers took courses and internships in the Netherlands, mainly to work at Verenigde Bloemenveiling Aalsmeer, translated as, Aalsmeer's United Flower Auctions; today FloraHolland in Amsterdam is the world's largest center of flowers and plants (Cavallaro et al., 2016).
Ornamental plant producers in Holambra rely on cooperatives to develop vertically integrated value chains, supported by cold storage facilities, packaging, and quality control systems that allow farmers to successfully compete in the national and international markets (Pereira et al., 2004).

Such level of coordination, investment, and scale is far from being the reality in many regions of Santa Catarina, such as Chapecó, where informality, low technology adoption, poor logistics, and lack of skilled labor remains predominant (Neves and Pinto, 2015). Similar observations were described by Muraro et al. (2015), for Curitiba city; according to the authors, in the commercial segment of ornamental plants in Curitiba, the related supply chain did not show interaction; thus, different actors in the supply chain were isolated. The authors emphasized that the success of cooperatives and associations is also based on their knowledge of market demands and trends and, their interactions with other actors in the supply chain.

\section{Ornamental plant outlets (flower shops and supermarkets)}

In this research, 18 ornamental plant commercial establishments were interviewed (three supermarkets and 15 flower shops) in different neighborhoods of Chapecó. For $89 \%$ of the establishments, the price was the top priority for consumers, followed by quality $(78 \%)$, appearance $(27 \%)$, and diversity (22\%). Flower shop managers have been particularly concerned with the fast expansion of ornamental plant spaces in supermarkets over the past few years. Because of economies of scale, supermarkets are frequently more competitive on price, a top priority for consumers. Moreover, there is an advantage of convenience as consumer spares time by shopping for groceries and, for instance, ornamental plants at the same space. Menegaes et al. (2015) found a similar trend in Santa Maria-RS, where sales of ornamental plants were gradually shifting from traditional outlets, such as flower shops, to relatively large local supermarket chains. At the national level, sales of ornamental plants in supermarkets grew $15 \%$ to $20 \%$ per year accounting, in 2015 , for $10 \%$ of the Brazilian ornamental plant retail market (SEBRAE, 2015).

Flower shops and supermarkets, nevertheless, agree that credible and trustworthy suppliers are essential to the success of the business. For $78 \%$ of the interviewed establishments for commercial ornamental plants, sales depend on a constant and reliable supply of diverse and high-quality plants (appearance and standardization) at a competitive price. Another important challenge is logistics. Other Brazilian regions have similar problems; for instance, according to Reis and Marafon (2020), in the state of Rio de Janeiro, lack of technical/administrative training for the chain's members, and deficient transportation and packaging, among others, are difficulties cited by Seapec (2015) as bottlenecks that hinder the development of this segment in Rio de Janeiro. 
The main ornamental plant supplies for commercial establishments in Chapecó is Holambra SP, followed by few other specialized wholesalers in Santa Catarina East coast and the Rio Grande do Sul. High quality, relatively low prices, and reliability are essential in designing the current supply chain connecting Chapecó to São Paulo and other regions (Menegaes et al., 2015).

In the 1950s, the establishment of major ornamental plant suppliers in São Paulo, particularly in the municipalities of Holambra and Atibaia, had a significant impact on the development of this sector across the country (Junqueira and Peetz, 2018). This region pioneered ornamental plant production and investment, which allowed the development of infrastructure and human resources like no other region in Brazil.

The high number of specialized ornamental plant suppliers in the Holambra region is associated with a shift in consumer preferences. Over the last three decades, ornamental plant purchases have been increasingly more homogeneous. This is because regional species - that are locally produced - are less competitive with the standardized quality and relatively low prices of industrial-scale production in Holambra (Sebrae, 2015; Junqueira and Peetz, 2018). Therefore, the produce from Holambra tends to be a more frequent purchase among ornamental plant consumers.

When confronted with a lack of local supply, $50 \%$ of the interviewed commercial establishments were positive toward the local production that can enable farmers to meet high-quality standards, and ensure a reliable supply throughout the year. Local production has the advantage of lower storage and transportation costs than shipments coming from São Paulo, for example. Besides, there may be quality advantages. Ornamental plants can easily perish under poor transportation conditions. Such losses are frequent in Chapecó, where sales outlets are fully dependent on external suppliers. Similar situations have been observed in several cities in Brazil; at Pelotas-RS, for instance, Fischer et al. (2015) found that distance between the production sites and the consumer market influences the quality and vase life of roses and gerberas marketed in Pelotas; shipping from São Paulo, for example, can take up to $24 \mathrm{~h}$ to reach wholesalers in the Rio Grande do Sul (Sebrae, 2003), and another $24 \mathrm{~h}$ to reach retail distribution, further reducing the period of use of flowers by the final consumer.

The commercial establishments that were interviewed, however, believe that there is no advantage in the local production of ornamental plants and that there will be no economic advantage owing to the unfavorable climate conditions (Chapecó is colder than São Paulo), and limited scale of production. These limitations would undermine the competitiveness of local ornamental plant production compared with traditional suppliers, mainly from São Paulo.

\section{Ornamental plant consumers}

The preference of consumers in Chapecó is rather diverse (Table 2). Nevertheless, they are overwhelmingly driven to potted plants. Except for roses, all other choices, as their favored ornamental plant, were potted plants. The list is headed by orchids, roses, and kalanchoes (Table 2).

Table 2. Most frequent choices of ornamental plants by consumers in Chapecó, State of Santa Catarina.

\begin{tabular}{|c|c|}
\hline Species & Frequency (\%) \\
\hline \multicolumn{2}{|c|}{ Cut flowers } \\
\hline Roses & 38 \\
\hline \multicolumn{2}{|c|}{ Potted plants } \\
\hline Orchids & 67 \\
\hline Kalanchoe & 29 \\
\hline Bonsai & 13 \\
\hline Succulents & 11 \\
\hline Chrysanthemums & 11 \\
\hline Lilies & 7 \\
\hline Violets & 7 \\
\hline Foliage & 7 \\
\hline Fruits & 7 \\
\hline Gerberas & 7 \\
\hline Tulips & 4 \\
\hline Pansy & 4 \\
\hline Daisies & 4 \\
\hline Azaleas & 4 \\
\hline Ferns & 4 \\
\hline Others & 22 \\
\hline
\end{tabular}


In terms of ornamental plants consumption, consumer preference for potted plants is cited by Junqueira and Peetz (2017) as a new trend; a growth in the consumption of potted plants can be explained because they present a better cost $x$ benefit to the consumer, greater durability and ease in the treatment and handling, requiring less care and dedicated time for the domestic maintenance, as well as the practicality of no need for vessels or containers specially available for ornamental purpose.

Such tendency in Brazil may be explained by the tendency of relatively low per capita expenditure on ornamental plants. Consumers seem to find more utility in plants that last longer, rather than in cut flowers. Yet another important driver for potted plants is quality. Cut flowers are extremely sensitive to storage. Therefore, the market for potted plants tends to be better in regions where the distribution of cut flowers is poorly done.

The consumption of ornamental plants in Chapecó is also skewed by commemorative dates. Most of the interviewed consumers sought ornamental outlets to buy a present, wherein, birthdays and Mother's day lead the list (Table 3). Anacleto et al. (2017) found similar results in several cities of the Paraná coast, where $87 \%$ of consumers bought flowers, mainly roses, for Mother's day, Valentine's day, and birthdays.

Table 3. Most common occasions for buying an ornamental plant in Chapecó.

\begin{tabular}{|c|c|}
\hline Date & Frequency (\%) \\
\hline Birthdays & 51 \\
\hline Mother's Day & 42 \\
\hline Every other day & 27 \\
\hline Day of the Dead & 20 \\
\hline Christmas & 7 \\
\hline Woman's Day & 4 \\
\hline Valentine's Day & 2 \\
\hline
\end{tabular}

In terms of value per acquisition, most consumers (71\%) spent, on average, between R\$ 10.00 to $\mathrm{R} \$ 50.00$ per year (Figure 2). However, 29\% of consumers spent more than R\$ 50.00 per acquisition. Our findings are similar to the values reported for state and national averages, which are $\mathrm{R} \$ 31.50$ and R \$ 30.00, respectively (Neves and Pinto, 2015; Junqueira and Peetz, 2018)both in its segment of cut flowers and foliage and in landscaping. The study is based on bibliographic review, data collection and interpretation on the recent performance of the flower and ornamental plants market in Brazil, with emphasis on the role played by the importation of genetic material from exotic species to support commercial activity in the country. From this phenomenon and the productive and distributive concentration of the flowers and plants in the State of Sao Paulo (Holambra, Santo Antônio de Posse, Campinas, Atibaia and Mogi das Cruzes).

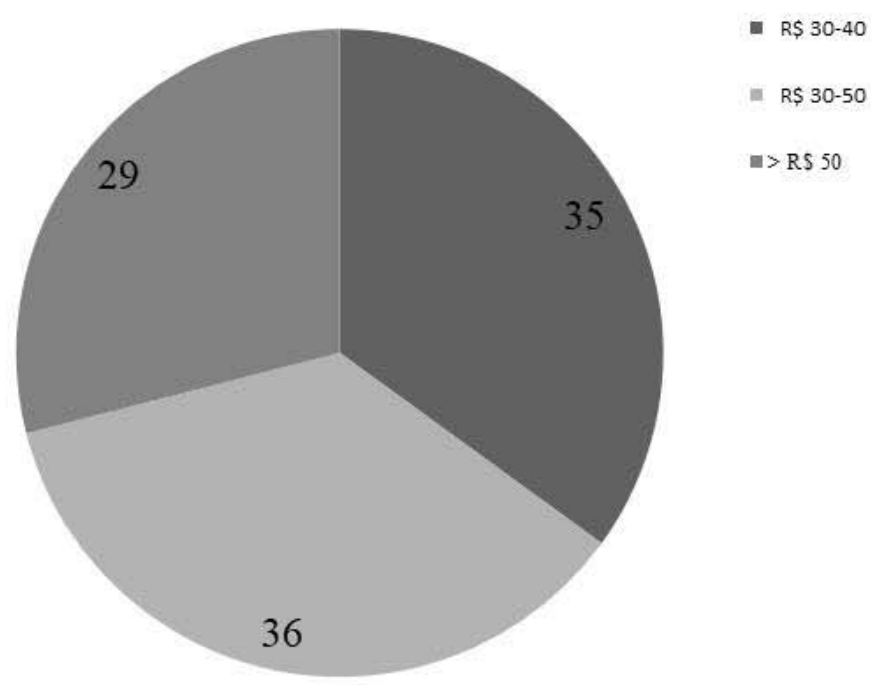

Figure 2. Average consumer expenditure per acquisition of ornamental plants in Chapecó, State of Santa Catarina. 
Another relevant aspect of the behavior of ornamental plants consumers is related to sustainability. In recent years the concept of "Sustainable Development" has become increasingly relevant for the society as well as for the economy; like in other areas focusing on consumer spending, the role of sustainability is increasing in the production, marketing, and consumption of ornamental plants. The economic development, the higher level of available per capita income, and a growing sensitivity to environmental aspects have led to profound changes in the purchasing behavior of consumers (Dominguez, Schoppe, Sparke, 2017).

Strategies that add value through sustainable management have been successful in the European Union (Mariotti and Roccotiell, 2013). Yet this practice remains somewhat restraint in many regions of Brazil, such as Chapecó where consumer preoccupation with sustainability remains low. For $75 \%$ of the consumers in Chapecó, the appearance (i.e., beauty) of the ornamental plant is one of the most important features observed ahead of any purchase, followed by price, which is valued by $60 \%$ of the consumers. Sustainability or sustainable management was not voluntarily mentioned by consumers as important factors affecting their decision making. There is, however, some self-awareness to the product origin; $27 \%$ of the consumers look for locally produced plants as a way to promote regional development. For $91 \%$ of the consumers, local production could boost availability and reduce prices, with positive impacts on the local demand for ornamental plants.

The consumers were also asked about their criteria for choosing a commercial outlet. Convenience and prices topped the list, being preferred by $55 \%$ and $51 \%$ of the consumers, respectively. Other factors, though less important, are product diversity, quality, and consumer service. As discussed earlier in this paper, over the past few years, supermarkets have successfully combined convenience with economies of scale (low prices), including those of ornamental plants. Consumers, therefore, buy ornamental plants in supermarkets and relatively small florists scattered around the city and only $8 \%$ of the consumers buy ornamental plants at the local farmers' market, where most of the local produce is sold. This is particularly concerning for family farmers who are often excluded from more specialized sales outlets, because of their inability to comply with volume, frequency, diversity, packaging, and, sometimes, quality. One of the main drawbacks of the local farmers' market is convenience. The venue is open only two days a week and for a few hours, while a supermarket is open seven days a week from morning to evening. Consumers have also reported the inconvenience to access farmers' markets in Tupã-SP as a reason to shop for ornamental plants in supermarkets (Cazane et al., 2014).

Our findings in this research show that there are many challenges in promoting ornamental plant production under family farms in Chapecó. Despite the opportunities for additional value, which is appropriate for small farms and relatively greater availability of family labor in the region, economic competitiveness is still a major setback for local production. Family farmers are not adequately suited to compete with the industrial-scale production of ornamentals from regions such as São Paulo (i.e., Holambra e Atibaia). Small-scale and lack of technical assistance undermines local farmers' ability to deliver quality products at competitive prices. Family farmers are often excluded from specialized market outlets (supermarkets and flower shops) in Chapecó, where 92\% of consumers buy ornamental plants. The reasons include farmers' inability to comply with volume, frequency, packaging, and quality standards.

Strategies to promote ornamental plant production in the Chapecó region and, therefore, to explore the large potential of family farms, may involve including nonconventional plants, and cooperation. The first strategy aims to foster species that are not supplied by large-scale producers from other regions (such as São Paulo). By exploring gaps in market practices, local farmers may successfully find opportunities to gain competitiveness, although regionally limited. The second strategy is collective action. Cooperatives can pave the way for farmers to gain bargaining power, reduce transaction costs, access technical assistance, and specialized market outlets. This concept is already prevalent in the state and in Chapecó. Agriculture cooperatives are a tradition in the region, where farmers have successfully achieved coordination at professional levels to access specialized markets, thus meeting volume, frequency, and quality requirements (Silva and Sousa, 2013). Combining cooperation with ornamental plant production (done in Holambra, for example) may require more than a few enthusiastic farmers. Polytechnic is also necessary to kick-off local initiatives in the form of developing programs to assist decision making, management, and marketing strategies. Despite being challenging, ornamental plants may be one of the needed alternatives for many exhausted family farmers who have been struggling with traditional production systems, based on dairy, poultry, and pork.

\section{Conclusions}

Commercialization is predominant in supermarket chains, for ease of access to consumers. The price of ornamental plants is the main factor in their commercialization, and the dearth of producers in the region, increases the values, especially due to the long transportation required.

\section{Author Contribution}

JS: conduction and evaluation of the experiment, writing of the manuscript; VNS: experimental planning, tabulation, and analysis of data, writing of the manuscript; JGDBL: analysis of data and writing of the manuscript. 


\section{Acknowledgements}

To all ornamental plant producers, sellers, and consumers who agreed to participate in this research.

\section{References}

ANACLETO, A.; NEGRELLE, R.R.B.; CUQUEL, F.C.; MURARO, D. Profile and behavior of flower consumer: subsidies for marketing actions. Revista Ceres, v.64, n.6, p.557-566, 2017. DOI: http://dx.doi.org/10.1590/0034$737 \times 201764060001$

ARCAS-LARIO, N.; MARTÍN-UGEDO, J.F.; MÍNGUEZVERA, A. Farmers' satisfaction with fresh fruit and vegetable marketing Spanish cooperatives: an explanation from agency theory. International Food and Agribusiness Management Review, v.17, n.1, p.127-146, 2014.

BERDEGUÉ, J.; REARDON, T.; BALSEVICH, F.; FLORES, L.; HERNANDÉZ, R. Supermarkets and small horticultural product farmers in Central America. In: SWINNEN, J.F.M. (Ed.). Global supply chains, standards and the poor: how the globalization of food systems and standards affects rural development and poverty. Wallingford: CABI, 2007. p.135-144.

BOEHLJE, M. Structural changes in the agricultural industries: how do we measure, analyze and understand them? American Journal of Agricultural Economics, v.81, n.5, p.1028-1041, 1999.

CAVALLARO, G.M.; FURLANETTI, E.W.; KRAKAUER, P.V.C. Cluster e desenvolvimento local: o caso da Cooperativa Veiling Holambra. Revista Espacios, v.37, n.9, p.11-23, 2016.

CAZANE, A.L.; MACHADO, J.G.C.F.; SAMPAIO, F.F. Análise das feiras livres como alternativa de distribuição de frutas, legumes e verduras (FLV). Informe Gepec, v.18, n.1, p.119-137, 2014.

CEPA. Síntese anual da agricultura Catarinense. Florianópolis: Centro de Socioeconomia e Planejamento Agrícola (Epagri/Cepa), 2018. 206p.

CHAPECÓ. Número de floriculturas em Chapecó. Chapecó: Prefeitura, secretaria municipal de Desenvolvimento Rural e Meio Ambiente. 2018.

DOMINGUEZ, G.B.; SCHOPPE, H.M.; SPARKE, K. Evaluation of existing research concerning sustainability in the value Chain of Ornamental Plants. European Journal of Sustainable Development, v.6, n.3, p.11-19, 2017. https://doi.org/10.14207/ejsd.2017.v6n3p11

DUVAL, C.M.A. Produção de flores e a agricultura familiar. Horticultura Brasileira, v.32, n.2, 2014.
FISCHER， S.Z.; STUMPF， E.R.T.; CASTRO, C.M.; BARBIEIRI, R.L.; HEIDEN, G. Durabilidade de rosas, gérberas e crisântemos comercializados em Pelotas-RS. Ornamental Horticulture, v.21, n.1, p.113-118, 2015. DOI: https://doi.org/10.14295/rbho.v21i1.783

HIGUCHI, A. Impact of a marketing cooperative on cocoa producers and intermediaries: the case of the acopagro cooperative in Peru. Journal of Rural Cooperation, v.42, n.1, p.80-97, 2014. DOI: https://doi.org/10.22004/ ag.econ. 249707

HUMMEL, M.; MIGUEL, L.A.P. Gerando valor na cadeia de flores de corte no mercado brasileiro. Práticas em Contabilidade e Gestão, v.5, n.1, p.176-191, 2017. DOI: $\quad h t t p: / / d x . d o i . o r g / 10.5935 / 2319-0485 /$ praticas. v5n1p176-191

IBGE- Instituto Brasileiro de Geografia e Estatística. Dados Preliminares do Censo Agropecuário 2017. Available at: $<$ https://censoagro2017.ibge.gov.br/templates/censo_agro/ resultadosagro/index.html >. Acessed on August 15, 2019.

IBGE. Instituto Brasileiro de Geografia e Estatística. Censo Demográfico. Rio de Janeiro: IBGE, 2018. Available at: $<$ https://www.ibge.gov.br/cidades-e-estados/sc/chapeco. html>. Accessed on January 10, 2019.

JUNQUEIRA, A.H.; PEETZ, M.S. Sustainability in Brazilian floriculture: introductory notes to a systemic approach. Ornamental Horticulture, v.24, n.2, p.155162, 2018. DOI: https://doi.org/10.14295/oh.v24i2.1253

JUNQUEIRA, A.H.; PEETZ, M.S.; Brazilian consumption of flowers and ornamental plants: habits, practices and trends. Ornamental Horticulture, v.23, n.2, p. 178-184, 2017.

MANIKAS, I.; MALINDRETOS, G.; ABELIOTIS, K. Sustainable Cities through alternative urban farming: the case of floriculture. Journal of International Food \& Agribusiness Marketing, 2019. DOI: https://doi.org/10.1 080/08974438.2019.1599762

MARIOTTI, M.G.; ROCCOTIELL, E. Sustainable floriculture: Handbook and Guidelines. Montecarrlo: Green Printing, 2013. 84p.

MELLO, M.A. A produção de 'novidades' como alternativa à crise pelos agricultores do oeste de Santa Catarina. Desafio Online, v.1, n.3, p.1-18, 2013.

MENEGAES, J.F.; BACKES, F.A.A.L.; BELLÉ, R.; BACKES, R. Diagnóstico do mercado varejista de flores de Santa Maria, RS. Ornamental Horticulture, v.21, n.3, p.291-298, 2015. DOI: https://doi.org/10.14295/ oh.v21i3.629 
MURARO, D.; NEGRELLE, R.R.B.; CUQUEL, F.L.; ANACLETO, A. Market management: the impact on the development of an ornamental plants supply chain in Curitiba, Brazil. Ciência e Investigación Agraria, v.42, n.3, p.453-460, 2015. DOI: http://dx.doi.org/10.4067/ S0718-16202015000300013

NASCIMENTO, C.A.; SOUZA, M.; STADUTO, J.R.; PAULI, R.P. Occupation and Pluriactivity of the Families in the Southern Region of Brazil. Agrociencia Uruguay, v.23, n.2, p.1-13, 2019. DOI: http://dx.doi.org/10.31285/ agro. 23.78

NEVES, M.F.; PINTO, M.J.A. Mapeamento e quantificação da cadeia de flores e plantas ornamentais do Brasil. São Paulo: OCESP, 2015. 132p.

PEREIRA, A.L.; LIMBERGER, P.F.; FLORES, L.C.S.; PEREIRA, M.L. An empirical investigation of destination branding: the case of the City of Rio de Janeiro, Brazil. Sustainability, v.11, n.1, p.90, 2019. DOI: https://doi. org/10.3390/su11010090

PEREIRA, J.P.C.N.; CAVALCANTI, M.; CARVALHO, M.M. Análise da competitividade do agronegócio de flores no Município de Holambra (SP) sob o enfoque da concentração geográfica de empresas-arranjos produtivos locais. Revista Administração em Diálogo-RAD, v.6, n.1, 2004. DOI: https://doi.org/10.20946/rad.v6i1.683

REARDON, T.; TIMMER, C. P.; MINTEN, B. Supermarket revolution in Asia and emerging development strategies to include small farmers. Proceedings of the National Academy of Sciences, v.109, n.31, p.12332-12337, 2012. DOI: https://doi.org/10.1073/pnas.1003160108

REIS, J.L.C.S.; MARAFON, G.J. A dimensão espacial da rede de flores e plantas ornamentais do estado do Rio de Janeiro: uma análise a partir do município de Nova Friburgo, entre os anos de 2002 e 2018. Geo UERJ, n.36, e47278, 2020. DOI: https://doi.org/10.12957/geouerj.2020.47278.

SEAPEC. Floricultura fluminense ganha espaço nacional para pleitear incentivos: ASBRAER é representada na Câmara Setorial de Floricultura e Plantas Ornamentais por gerente estadual da Emater-Rio. Available at: $<$ http://www.rj.gov.br/web/seapec/exibeconteudo?article$\mathrm{id}=2512331>$. Acessed october 10, 2019.
SEBRAE. Diagnóstico da cadeia produtiva de flores e plantas ornamentais do Rio Grande do Sul. Porto Alegre: Editora Vangraf, 2003. 159p.

SEBRAE. Flores e plantas ornamentais do Brasil. Vol.1. Brasília: Serviço Brasileiro de Apoio às Micro e Pequenas Empresas-Sebrae, 2015. 44p.

SILVA, A.P.F.; SOUSA, A.A. Alimentos orgânicos da agricultura familiar no Programa Nacional de alimentação Escolar do Estado de Santa Catarina, Brasil. Revista de Nutrição, v.26, n.6, p.701-714, 2013. DOI: https://doi. org/10.1590/S1415-52732013000600009

SPALLA, L.R.; CASTILHO, S.R. Medication reconciliation as a strategy for preventing medication errors. Brazilian Journal of Pharmaceutical Sciences, v.52, n.1, p.143-150, 2016. DOI: http://dx.doi.org/10.1590/ S1984-82502016000100016

TEIXEIRA, M.G.; ROGLIO, K.D.; MARCON, R. Institutional logics and the decision-making process of adopting corporate governance at a cooperative organization. Journal of Management and Governance, v.21, p.181-209, 2017. DOI: https://doi.org/10.1007/ s10997-016-9340-X

TERRA, S.B.; ZÜGE, D.P.P.O. Floricultura: a produção de flores como uma nova alternativa de emprego e renda para a comunidade de Bagé-RS. Revista Conexão UEPG, v.9, n.2, p.342-353, 2013.

VAN DER MEER, C. Exclusion of small-scale farmers from coordinated supply chains. IN: RUBEN, R.; SLINGERLAND, M.; NIJHOFF, H. (Eds.). Agro-Food Chains and Networks for Development. Netherlands: Springer, 2006. p.209-2017. 